\title{
The Role of Phyto-Melatonin and Related Metabolites in Response to Stress
}

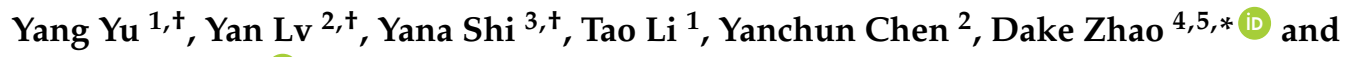 \\ Zhiwei Zhao ${ }^{1, *}$ (D) \\ 1 State Key Laboratory for Conservation and Utilization of Bio-resources in Yunnan, Yunnan University, \\ Kunming 650091, China; YuYang_YNU@163.com (Y.Y.); litao@ynu.edu.cn (T.L.) \\ 2 School of Agriculture, Yunnan University, Kunming 650504, China; lvyanshj@163.com (Y.L.); \\ lqhclucky@163.com (Y.C.) \\ 3 Institute of Medicinal Plants, Yunnan Academy of Agricultural Sciences, Kunming 650205, China; \\ bestshiyana@163.com \\ 4 Biocontrol Engineering Research Center of Plant Disease \& Pest, Yunnan University, Kunming 650504, China \\ 5 Biocontrol Engineering Research Center of Crop Disease \& Pest, Yunnan University, Kunming 650504, China \\ * Correspondence: zhaodk2012@ynu.edu.cn (D.Z.); zhaozhw@ynu.edu.cn (Z.Z.); \\ Tel.: +86-0871-6522-7730 (D.Z. \& Z.Z.) \\ + These authors contributed equally to this work.
}

Academic Editor: Dun-Xian Tan

Received: 28 June 2018; Accepted: 26 July 2018; Published: 28 July 2018

\begin{abstract}
Plant hormone candidate melatonin has been widely studied in plants under various stress conditions, such as heat, cold, salt, drought, heavy metal, and pathogen attack. Under stress, melatonin usually accumulates sharply by modulating its biosynthesis and metabolic pathways. Beginning from the precursor tryptophan, four consecutive enzymes mediate the biosynthesis of tryptamine or 5-hydroxytryptophan, serotonin, $\mathrm{N}$-acetylserotonin or 5-methoxytryptamine, and melatonin. Then, the compound is catabolized into 2-hydroxymelatonin, cyclic-3-hydroxymelatonin, and $N^{1}$-acetyl- $N^{2}$-formyl-5-methoxyknuramine through 2-oxoglutarate-dependent dioxygenase catalysis or reaction with reactive oxygen species. As an ancient and powerful antioxidant, melatonin directly scavenges ROS induced by various stress conditions. Furthermore, it confreres stress tolerance by activating the plant's antioxidant system, alleviating photosynthesis inhibition, modulating transcription factors that are involved with stress resisting, and chelating and promoting the transport of heavy metals. Melatonin is even proven to defense against pathogen attacks for the plant by activating other stress-relevant hormones, like salicylic acid, ethylene, and jasmonic acid. Intriguingly, other precursors and metabolite molecules involved with melatonin also can increase stress tolerance for plant except for unconfirmed 5-methoxytryptamine, cyclic-3-hydroxymelatonin, and $N^{1}$-acetyl- $N^{2}$-formyl-5-methoxyknuramine. Therefore, the precursors and metabolites locating at the whole biosynthesis and catabolism pathway of melatonin could contribute to plant stress resistance, thus providing a new perspective for promoting plant stress tolerance.
\end{abstract}

Keywords: melatonin; reactive oxygen species; biosynthesis; catabolism; stress resistance

\section{Introduction}

Melatonin ( $\mathrm{N}$-acetyl-5-methoxytryptamine), which is widespread in almost all organisms, appears to be a multi-regulatory molecule with multiple functions in plant growth and development, such as seed germination, root development, fruit ripening, senescence, yield, circadian rhythm, and response to stress [1-3]. Under various abiotic and biotic stresses, such as heat, cold, salt, drought, heavy metal, and pathogen attack, melatonin usually could directly scavenge ROS generating from these stresses as 
a powerful antioxidant, thus promoting the stress resistance for plants [1,4-7]. Furthermore, melatonin could improve stress tolerance by activating the plant's antioxidant system, alleviating photosynthesis inhibition, modulating transcription factors that are involved with stress resisting, chelating and promoting transport of heavy metals, or activating other stress-relevant hormones, like salicylic acid, ethylene, and jasmonic acid [8-11]. Therefore, phyto-melatonin (melatonin in plants) plays the key role in plant stress response.

It is well understood that the biosynthesis of phyto-melatonin begins with tryptophan and it involves several intermediates, including tryptamine, 5-hydroxytryptophan, serotonin, $N$-acetylserotonin, and 5-methoxytryptamine [12]. Thereafter, melatonin is converted into other metabolites, including 2-hydroxymelatonin, cyclic-3-hydroxymelatonin, or $N^{1}$-acetyl- $N^{2}$-formyl-5-methoxyknuramine (AFMK) [13,14]. Previous research showed that, besides melatonin, its precursors and metabolites also participated in the plant stress resistance (Table 1). Though these compounds that are involved in the synthesis and metabolism pathways of melatonin play a role in stress resistance $[15,16]$, no review is available focusing on the complete biosynthesis and catabolism pathway of melatonin under various abiotic and biotic stresses. Herein, the role of phyto-melatonin and its precursors and metabolites in response to stress is reviewed, thus providing a new perspective for promoting plant stress resistance.

Table 1. Melatonin and its precursors and metabolites mediating plant stress resistance.

\begin{tabular}{|c|c|c|}
\hline Compounds & Stresses & Plant Species \\
\hline melatonin & cold & $\begin{array}{c}\text { Arabidopsis thaliana }[17,18], \text { Solanum lycopersicum }[19,20], \text { rice [21], } \\
\text { Prunus persica [22], Citrullus lanatus [23], Triticum aestivum [24], } \\
\text { and Cucumis sativus [25] }\end{array}$ \\
\hline melatonin & heat & $\begin{array}{l}\text { Arabidopsis thaliana [26], Solanum lycopersicum }[27,28] \\
\text { Lolium perenne }[29], \text { and Festuca arundinacea }[30]\end{array}$ \\
\hline melatonin & salt & $\begin{array}{l}\text { Arabidopsis thaliana [31,32], Cucumis sativus [33], } \\
\text { Citrullus lanatus [34], Helianthus annuus [35], and Zea mays [36] }\end{array}$ \\
\hline melatonin & drought & $\begin{array}{l}\text { Arabidopsis thaliana [37], Malus zumi [38], Solanum lycopersicum [39], } \\
\text { Zea mays [40,41], Triticum aestivum [42], and Medicago sativa [43] }\end{array}$ \\
\hline melatonin & heavy metal & $\begin{array}{c}\text { rice [44-46], Solanum lycopersicum [47,48], Medicago sativa [49], } \\
\text { Citrullus lanatus [50], and wheat [51] }\end{array}$ \\
\hline melatonin & pathogen & $\begin{array}{l}\text { Arabidopsis thaliana [52-54], rice [55], Musa acuminate [56], } \\
\text { potato [57], cassava [58], and Malus pumila [59] }\end{array}$ \\
\hline tryptamine & pathogen & rice $[60]$ \\
\hline serotonin & salt & Helianthus annuus [61] \\
\hline Serotonin & radiation & Vicia faba [62] \\
\hline Serotonin & heavy metal & rice [44] \\
\hline$N$-acetylserotonin & pathogen & Arabidopsis thaliana [63] \\
\hline 2-hydroxymelatonin & combination of cold and drought & rice [64] \\
\hline 2-hydroxymelatonin & pathogen & Arabidopsis thaliana [63] \\
\hline
\end{tabular}

\section{The Biosynthesis and Catabolism Pathway of Melatonin}

The biosynthetic pathway of phyto-melatonin has been elucidated recently (Figure 1). The molecule is produced via four consecutive enzymatic steps with tryptophan as the initial substrate and at least six enzymes are involved in melatonin synthesis, including TPH, TDC, T5H, SNAT, ASMT, and COMT [65]. Excluding TPH, genes encoding other five enzymes have been cloned [12,66-69]. The first enzymic step is the decarboxylation of tryptophan catalyzed by TDC to produce tryptamine in the cytoplasm, followed by the enzymatic hydroxylation by $\mathrm{T} 5 \mathrm{H}$ to generate serotonin in the endoplasmic reticulum [70]. For serotonin synthesis, alternatively, tryptophan may first be hydroxylated by one TPH (un-identified) in the cytoplasm in order to generate 5-hydroxytryptophan, followed by decarboxylated with TDC to produce serotonin in the cytoplasm [71]. Afterwards, both SNAT and ASMT, through acetylation and methylation, respectively, convert the substrate serotonin into $\mathrm{N}$-acetylserotonin in the chloroplast and 5-methoxytryptamine in the cytoplasm. These two intermediates are then converted to melatonin by ASMT in the cytoplasm or SNAT in 
the chloroplast [72,73]. Interestingly, COMT, an enzyme that is similar to ASMT, was reported to play a pivotal role in the synthesis of phyto-melatonin, specifically existing in the cytoplasm of plants $[65,74]$.

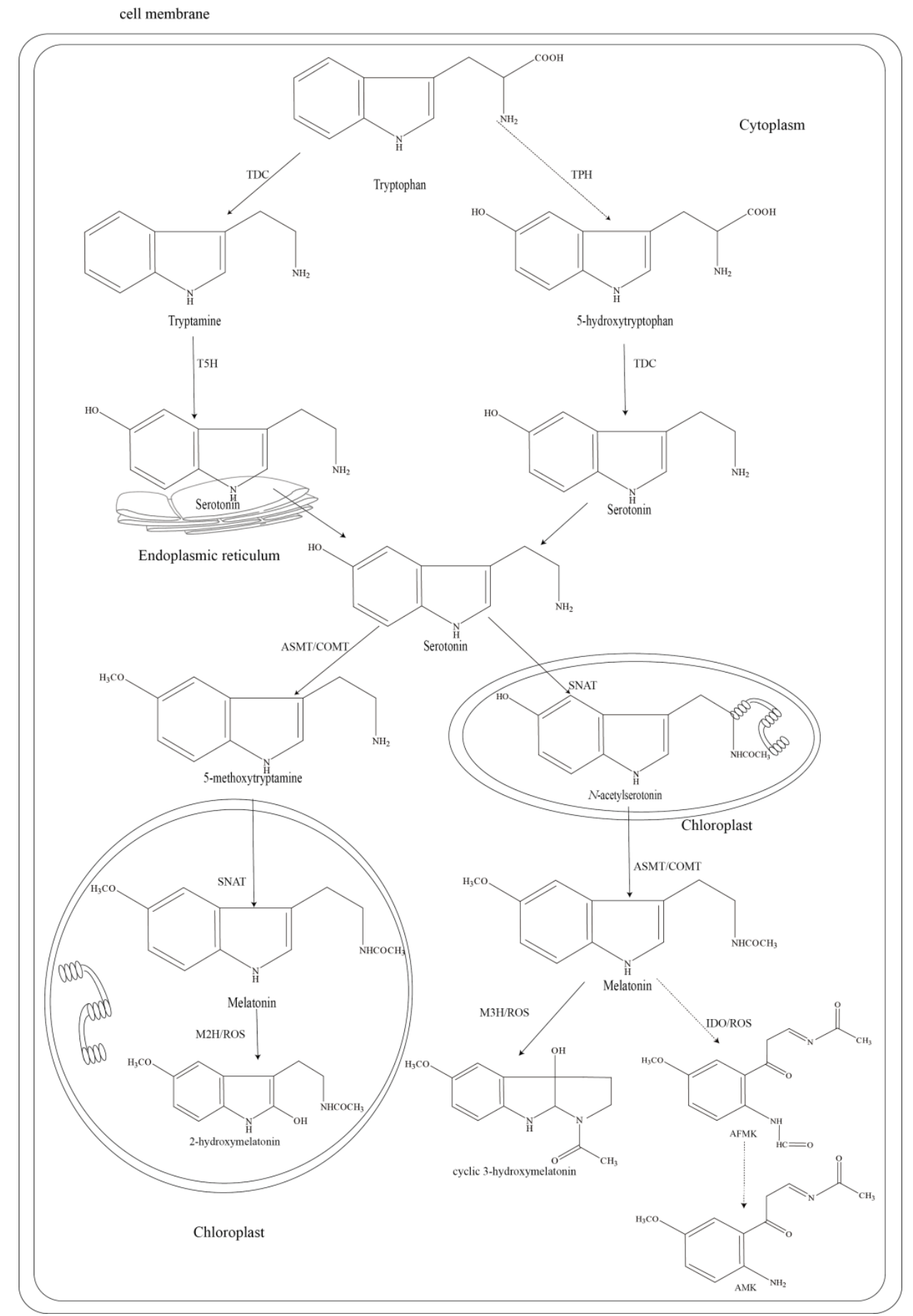

Figure 1. Melatonin biosynthesis and catabolism pathways in plants. Abbreviation: TDC, tryptophan decarboxylase; TPH, tryptophan hydroxylase; T5H, tryptamine 5-hydroxylase; SNAT, serotonin $\mathrm{N}$-acetyltransferase; ASMT, $\mathrm{N}$-acetylserotonin methyltransferase; COMT, caffeic acid $\mathrm{O}$-methyltransferase; AFMK, $N^{1}$-acetyl- $N^{2}$-formyl-5-methoxyknuramine; AMK, N-acetyl-5-methoxyknuramine; M2H, melatonin 2-hydroxylase; $\mathrm{M} 3 \mathrm{H}$, melatonin 3-hydroxylase; IDO, indoleamine 2,3-dioxygenase; 2-ODD, 2-oxoglutarate-dependent dioxygenase; ROS, reactive oxygen species. Dotted arrows represent the hypothetical steps. 
Compared to biosynthesis, limited information is available about phyto-melatonin catabolism. Several metabolites of melatonin have been detected in plants, including 2-hydroxymelatonin, cyclic-3-hydroxymelatonin, and AFMK [13]. These metabolites are formed through either enzymatic process or interactions between melatonin and ROS (Figure 1). AFMK, the first detected phyto-melatonin metabolite in water hyacinth (Eichhornia crassipes), is thought to produce via the catalysis of indoleamine 2,3-dioxygenase (IDO) [75-77]. AFMK can be further converted into AMK in animals and it is considered to exist in plants as well [13]. Furthermore, melatonin can be hydroxylated by members of 2-oxoglutarate-dependent dioxygenase (2-ODD) superfamily, among which 2-ODD 11, 19, 21, and 33 catalyzed the formation of 2-hydroxymelatonin [76] and 2-ODD 11, 26, and 33 catalyzed the conversion to cyclic-3-hydroxymelatonin in Arabidopsis [77]. Melatonin also can directly interact with ROS, further generating 2-hydroxymelatonin, cyclic-3-hydroxymelatonin, or AFMK [11]. The conversion of 2-hydroxymelatonin and cyclic-3-hydroxymelatonin to other unidentified products has not been reported in plants, however, the possibility cannot be excluded. More studies are needed to gain a better understanding of the mechanism of melatonin catabolism in plants.

\section{Stress-Induced Melatonin Accumulation}

It is widely reported that the production of phyto-melatonin is enhanced under different stresses, including heat, cold, drought, salinity, oxidation, heavy metal, or pathogen invasion [1,78], demonstrating that the molecule functions in the stress response. Phyto-melatonin accumulation is relatively closely associated with the gene expression and enzymic activity of the candidates lying on the biosynthesis and catabolism pathway of the melatonin under stress. For instance, the expression of melatonin synthetases (TDC, T5H, and ASMT) closely related to melatonin production in rice under excess Cd [44]. Besides, high temperature modulated the enzymic activities of SNAT and ASMT and further increased melatonin production in rice [79]. However, little is known about the pathway regulation mechanism of the production of melatonin in the response to stress. Recently, a transcription factor $(H s f A 1 a)$ was found to directly bind to the COMT1 gene promoter under Cd stress, and then increase the concentration of melatonin in tomatoes [47].

Generally, the divergence of molecules concentrations closely connects with precursor availability [1]. In contrast to expectation, a serotonin boost in the biosynthesis pathway of melatonin is not linked with a significant rise in melatonin due to the lower catalytic efficiency of ASMT/COMT and SNAT when compared to that of TDC and T5H [80]. Given the low enzyme activity, previous studies mainly through modulating the expression of SNAT/ASMT from plants or HIOMT (the homologous gene of ASMT in animals) to analysis the role of endogenous phyto-melatonin exposed to stress, further confirming that melatonin confers plant stress tolerance (Table 2). In addition, serotonin seems to play the same role in defense against stress under cold condition in rice [81]. Similarly, the higher levels of 2-hydroxymelatonin suffered from a combination of cold and drought in rice suggested its potential functions in resisting stresses [76,77].

Table 2. Melatonin-related transgenic plants under stress.

\begin{tabular}{ccc}
\hline Genetically Modified Plants & Melatonin Level ( $\uparrow$ up $\downarrow$ down) & Stress Resistance \\
\hline $\begin{array}{c}\text { human SNAT /HIOMT overexpressed } \\
\text { in Nicotiana sylvestris [82] }\end{array}$ & $\uparrow$ & $\begin{array}{c}\text { increased resistance to } \\
\text { UV-B radiation }\end{array}$ \\
\hline $\begin{array}{c}\text { human SNAT overexpressed in } \\
\text { transgenic rice [81] }\end{array}$ & $\uparrow$ & increased cold resistance \\
\hline $\begin{array}{c}\text { Sheep HIOMT overexpressed in } \\
\text { micro-tom tomato [83] }\end{array}$ & $\uparrow$ & increased resistance to drought \\
\hline SNAT knockout mutant Arabidopsis [84] & $\downarrow$ & $\begin{array}{c}\text { increased the susceptibility to } \\
\text { avirulent pathogen }\end{array}$ \\
\hline
\end{tabular}


Table 2. Cont.

\begin{tabular}{ccc}
\hline Genetically Modified Plants & Melatonin Level ( $\uparrow$ up $\downarrow$ down) & Stress Resistance \\
\hline suppression of SNAT / ASMT in rice [85] & $\downarrow$ & $\begin{array}{c}\text { increased the abiotic } \\
\text { stress susceptibility }\end{array}$ \\
\hline $\begin{array}{c}\text { maize ASMT overexpressed } \\
\text { in Arabidopsis [37] }\end{array}$ & $\uparrow$ & enhanced drought tolerance \\
\hline $\begin{array}{c}\text { tomato ASMT overexpressed } \\
\text { in tomato [27] }\end{array}$ & $\uparrow$ & enhanced thermotolerance \\
\hline $\begin{array}{c}\text { SNAT knockout mutant Arabidopsis [31] } \\
\text { ovine AANAT/HIOMT overexpressed } \\
\text { in switchgrass [86] }\end{array}$ & $\downarrow$ & decreased salinity tolerance \\
\hline rice SNAT overexpressed in rice [46] & $\uparrow$ & improved salt-tolerance \\
\hline $\begin{array}{c}\text { alfalfa SNAT overexpressed } \\
\text { in Arabidopsis [49] }\end{array}$ & $\uparrow$ & conferred resistance to cadmium \\
\hline
\end{tabular}

\section{Melatonin, its Precursors and Metabolites Conferring Plant Abiotic Stress Resistance}

Under abiotic stress, there are two major sources of ROS generating at apoplast (signaling ROS) and cellular compartments, including chloroplast, peroxisome, and mitochondria (metabolic ROS) [87]. Metabolic ROS together with signaling ROS moving into the cytoplasm via aquaporins up-regulates melatonin production [88-90]. However, an excess of ROS leads to lipid peroxidation in cellular membranes, DNA damage, protein denaturation, carbohydrate oxidation, pigment breakdown, and impaired enzyme activity [91]. Therefore, plants have to maintain a balance between ROS generation and ROS scavenging under stress. Phyto-melatonin is one of the key ways to clear excessive ROS and cope with kinds of abiotic stress with other measures (Figure 2).

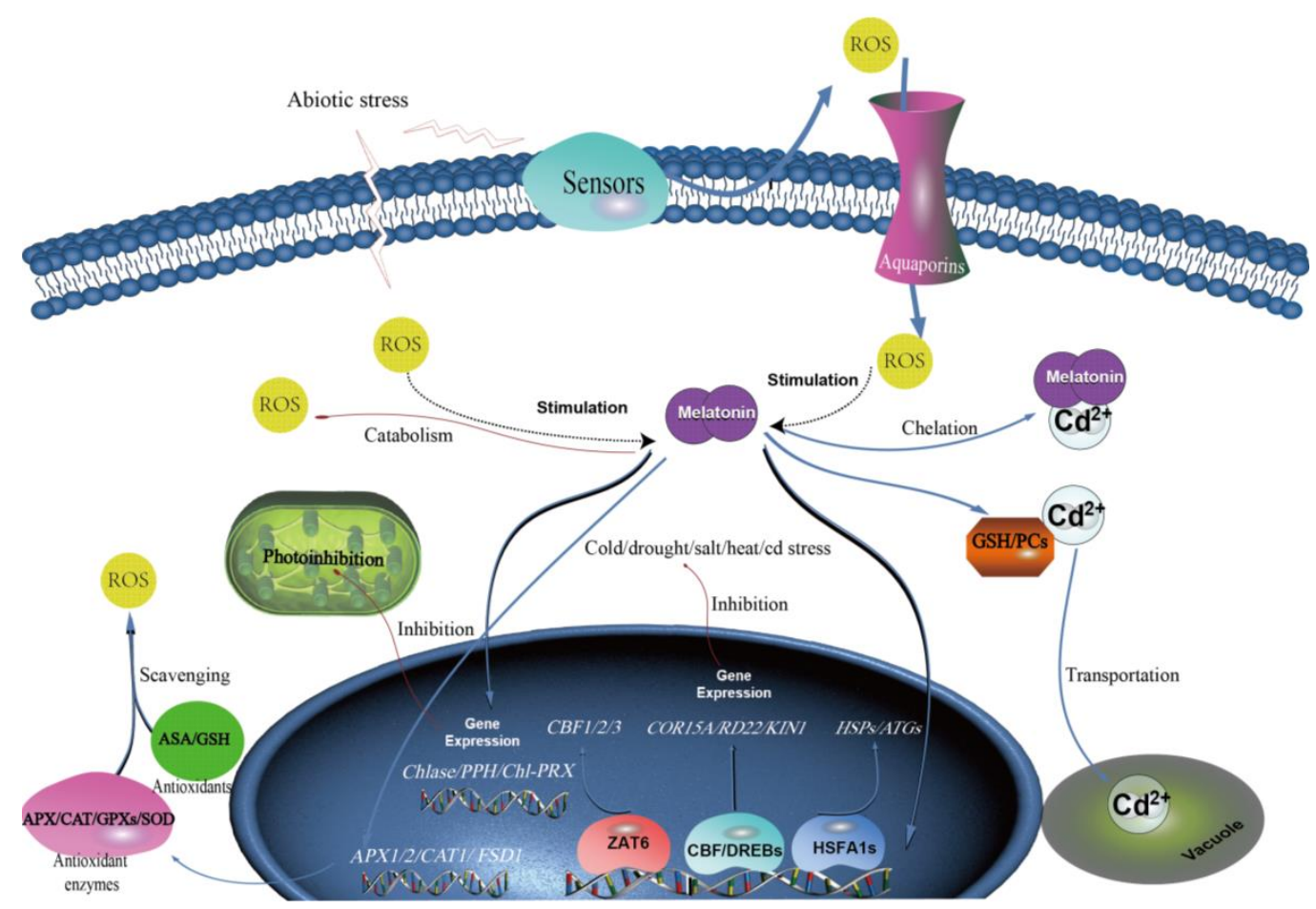

Figure 2. Melatonin-mediated abiotic stress response in plants. Abbreviation: ROS, reactive oxygen species; GSH, glutathione; PCs, phytochelatins; Cd, cadmium; SOD, superoxide dismutase; APX, ascorbate peroxidase; CAT, catalase; GPX, glutathione peroxidase; ASA, antioxidants ascorbic acid; GSH, glutathione. Dotted arrows represent the hypothetical pathway. 
Melatonin can directly scavenge ROS and then produce at least three metabolites (2-hydroxymelatonin, cyclic-3-hydroxymelatonin, and AFMK). It has the higher capacity to scavenge ROS than the classic antioxidants, such as including vitamin C, vitamin E, glutathione, and NADH [11,92-94]. Expect clearing ROS, melatonin also can directly bind to several toxic metals to suppress damage formation [95]. Exogenous melatonin significantly decreased the accumulation of vanadium in Citrullus lanatus, and cadmium in rice and Arabidopsis, and further reducing the heavy metal stress $[46,49,50]$.

In addition to directly interacting with ROS, melatonin can also activate the plant's antioxidant system. ROS-scavenging enzyme systems, such as superoxide dismutase (SOD), ascorbate peroxidase (APX), catalase (CAT), glutathione peroxidase (GPX), the antioxidants ascorbic acid (ASA), glutathione (GSH), and tocopherol play an important role in plant stress response [96,97]. Exposed to various stresses, melatonin usually up-regulates the content of SOD, APX, CAT, and GPX in plants by regulating antioxidant-related genes expression. For instance, melatonin induced expression of CAT1, APX1, and $F e-S O D$ under high temperature in Solanum lycopersicum [28]. Melatonin was also reported to increase the activities of APX, CAT, and SOD by up-regulating APX1/2, CAT1, and FSD1 transcripts in Arabidopsis in response to salt stress [31]. The relative expressions of several genes that are responsible for SOD, APX, and GPX were augmented in melatonin-treated seedlings exposed to vanadium stress in watermelon [50]. Furthermore, melatonin could activate the ASA-GSH cycle, an important antioxidant system in higher plants, to protect against abiotic stress. Under drought stress, the increased enzyme activity and expression of APX, dehydroascorbate reductase (DHAR), and monodehydroascorbate reductase (MDHAR) were responsible for melatonin-mediated increased GSH/(GSH + GSSG) and AsA/(ASA + DHA) in wheat seedlings [42]. GSH and ASA were substantially up-regulated as well in melatonin-treated tomato under cold stress [19]. Phyto-melatonin also enhanced contents of GSH and phytochelatins (PCs) in tomatoes under cadmium (Cd) stress, and then ATP-binding cassette transporters actively transported Cd-PCs and Cd-GSH complexes into the vacuole [47], contributing to heavy metal stress resistance by mediating sequestration or chelation [51].

Photosynthesis is highly sensitive to temperature, drought, salt, and heavy metal, and usually suppressed when exposed to these stresses [98]. Melatonin can enhance chlorophyll contention, electron transport, and stomatal conductance to alleviate photosynthetic inhibition that is caused by stress [9-11]. By down-regulating the chlorophyll degradation genes (chlorophyllase (Chase), pheophytinase $(P P H)$ and Chl-degrading peroxidase (Chl-PRX)), melatonin protects chlorophyll of plants from various stresses $[21,34,40,51,99]$. Melatonin application also regulated electron transport system, such as improving nonphotochemical quenching (NPQ) or photochemical quenching (qP), and further increased the maximal quantum yield of PSII photochemistry ( $\mathrm{Fv} / \mathrm{Fm})[34,41]$. Furthermore, exogenous melatonin raised stomatal conductance to relieve the limitation of $\mathrm{CO}_{2}$ that is caused by drought [40].

Transcription factors regulation is one of the critical ways of the phyto-melatonin-mediated stress response. Three melatonin-mediated abiotic stress transcription factors (Zinc Finger protein 6 (ZAT6), Heat Shock Factors (HSFA1s), and C-Repeat-Binding Factor (CBF)/Drought Response Element Binding 1 Factors (DREB1s)) were detected in plants. Melatonin up-regulated ZAT6 expression, which activated the CBF pathway and further mediated the freezing stress response [78]. HSFA1s, induced by melatonin, could up-regulate the transcription levels of the heat-response genes HSFA2, HSA32, HSP90, and HSP101, further conferring thermotolerance and Cd tolerance [26,47]. Meanwhile, the up-regulation of $C B F / D R E B 1 s$ closely associated with high level of melatonin led to an increase in the transcription levels of multiple stress-responsive genes (cold-related 15A (COR15A), responsive to dehydration 22 (RD22), and cold-inducible 1 (KIN1)), resulting in improved resistance to salt, drought, and freezing stresses [100]. Transcription factors activated by melatonin under abiotic stress play important roles in regulating the transcription of stress-responsive genes. Notably, 2-hydroxymelatonin, the metabolite of melatonin, also up-regulated the transcription factors Myb4 and AP37 to alleviate the effects of multiple abiotic stresses in rice [64]. 
Similar to melatonin, related intermediates and metabolites can also initiate plant stress response. Tryptophan, the primary precursor of phyto-melatonin, is also the substrate for auxin, glucosinolates, phytoalexins, alkaloids, and indoles, therefore it is an important molecule for the plant stress response [101,102]. For tryptamine, it is closely related with the light-enhanced resistance in rice [103]. Serotonin was reported to enhance a diverse range of abiotic stress responses, including improving survival under salinity by mediating the influx of ions into chloroplasts [104], enhancing the heavy metal tolerance through the high capacity for binding cadmium to form stable complexes [8], and relieving X-ray radiation stress [62]. It is worth noting that 2-hydroxymelatonin was amplified in rice in response to cold and drought stress [64]. The role of $N$-acetylserotonin in plants abiotic stress has not been identified, but $\mathrm{N}$-acetylserotonin exhibited antioxidant activity in animals [105]. The involvement of 5-methoxytryptamine, cyclic-3-hydroxymelatonin, and AFMK in the enhancement of plant stress resistance remains un-explored until now, but may potentially contribute to stress response based upon their molecular similarity with melatonin.

\section{Melatonin and Its Precursors and Metabolites Play Key Roles in Plant Biotic Stress}

Plants have evolved a melatonin immune system to protect individual cells against pathogen infection (Figure 3). Pathogen invasion induces plants to produce ROS by effectors or pathogen-microbe-associated molecular patterns (PAMPs or MAMPs) $[106,107]$. Similar to abiotic stress, ROS leading to the up-regulation of melatonin is observed upon infection by pathogens, however, the mechanism is not yet clear [54]. The role of melatonin in defense against pathogen attacks has been investigated in terms of the signaling pathway and mechanisms that are involved, among which the interaction of melatonin with salicylic acid (SA) is particularly important [54]. SA is an important defense hormone that is involved in the innate plant immunity [10], and it increases the transcript levels of a defense-gene (pathogenesis-related 1 (PR1)) by a receptor nonexpressor of PR1 (NPR1). High level of melatonin could indirectly induce transcription of isochorismate synthase 1 (ICS1), which is responsible for the biosynthesis of SA, by stimulating the mitogen-activated protein kinase (MAPK) cascade (MAPKKK3/OXI1-MAPKK4/5/7/9-MAPK3/6) in Arabidopsis thaliana infected with Pseudomonas syringe pv. Tomato (Pst) DC3000 [52,54]. Besides MAPKs, nitric oxide $(\mathrm{NO})$ also induces the innate plant immunity via positively modulating the expression levels of both SA synthesis genes (AtEDS1 and AtPAD4) and downstream SA resistant genes (AtPR1, AtPR2, and AtPR5) [53,108]. Intriguingly, melatonin induced augmented the transcription of $C B F / D R E B 1 s$, leading to an increase in NO by enhancing the accumulation of soluble sugars in Arabidopsis thaliana infected with Pst DC3000 [100]. Ethylene (ET) and jasmonic acid (JA) are involved in melatonin-mediated disease resistance as well [109]. For example, melatonin up-regulated 1-aminocyclopropane-1-carboxylate synthase 6 (ACS6), which is a key enzyme in the biosynthesis of $\mathrm{ET}$, and then induced expression of an antimicrobial peptide (plant defensin 1.2 (PDF1.2)) via ethylene insensitive 2 (EIN2) [52]. As JA could induce the expression of PDF1.2 as well as melatonin, we cannot rule out the possible involvement of JA with melatonin in the pathogen resistance pathway [52]. Additionally, MaHSP90s was reported to be up-regulated by melatonin triggered the effects of defense-related plant hormones (IAA, SA, JA, and ET) [56]. It is notable that transcriptome data analysis of melatonin-treated watermelon and Arabidopsis showed that various defense-related genes that were involved in plant hormone signaling or innate plant immunity, and the further analysis could lead to deep insight in molecular mechanisms of pathogen resistance for plants treated with melatonin $[110,111]$.

Similar to melatonin, serotonin may also be essential in long distance and rapid signaling in response to pathogen attacks by mediating ROS and interacting with hormone signaling networks [16]. The indole alkaloid tryptamine, a key factor in light-enhanced resistance, inhibited infection by Magnaporthe oryzae in rice [60]. 2-hydroxymelatonin and $N$-acetylserotonin could also activate MAPKs to confer the biotic stress, but to a lesser degree than melatonin in Arabidopsis thaliana [63]. 


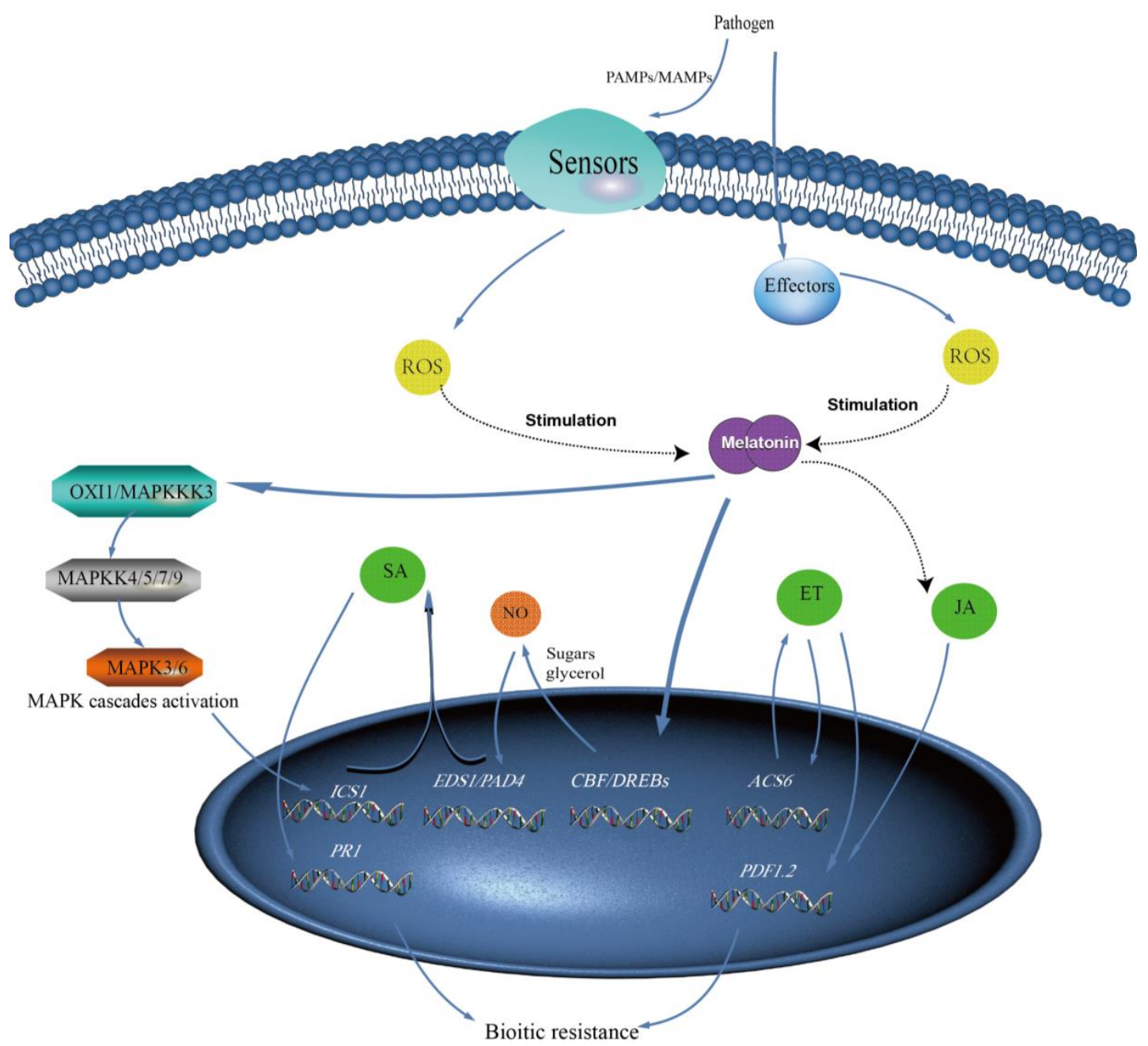

Figure 3. Melatonin-mediated biotic stress response in plants. Abbreviation: ROS, reactive oxygen species; PAMPs, pathogen-associated molecular patterns; MAMPs, microbe-associated molecular patterns; MAPK, Mitogen-activated protein kinase; NO, nitric oxide; SA, salicylic acid; JA, jasmonic acid; ET, ethylene. Dotted arrows represent the hypothetical pathway.

\section{Conclusions}

Faced with environmental changes, melatonin biosynthesis, and catabolism pathway would take essential functions in plants for coping with various stresses. Phyto-melatonin with its precursors and metabolites were adjusted to mitigate abiotic stress through both direct (scavenging ROS and chelating heavy metal) and indirect (activating the plant's antioxidant system, transporting heavy metal, alleviating photosynthesis inhibition, and regulating transcription factor) mechanisms. Moreover, melatonin imposes plant anti-pathogenic functions by activation of plant stress-relevant hormones, such as SA, ET, or JA. For a long time, previous studies have focused on how melatonin increases the abiotic and biotic stress resistance of plants. However, little attention has been given to the compounds located in the synthesis and catabolism pathway of melatonin. Further investigations on the role of precursors and metabolites of melatonin will shed more light on the underlying plant stress resistance.

Funding: This research was funded by the National Natural Science Foundation of China (81560622).

Conflicts of Interest: None of the authors have a conflict of interest. 


\section{Abbreviations}

\begin{tabular}{|c|c|}
\hline AFMK & $N^{1}$-acetyl- $N^{2}$-formyl-5-methoxyknuramine \\
\hline $\mathrm{AMK}$ & $N$-acetyl-5-methoxyknuramine \\
\hline 2-ODD & 2-oxoglutarate-dependent dioxygenase \\
\hline ROS & reactive oxygen species \\
\hline SA & salicylic acid \\
\hline $\mathrm{ET}$ & ethylene \\
\hline $\mathrm{JA}$ & jasmonic acid \\
\hline $\mathrm{TPH}$ & tryptophan hydroxylase \\
\hline TDC & tryptophan decarboxylase \\
\hline $\mathrm{T} 5 \mathrm{H}$ & tryptamine 5-hydroxylase \\
\hline SNAT & serotonin $N$-acetyltransferase \\
\hline ASMT & $N$-acetylserotonin methyltransferase \\
\hline COMT & caffeic acid $O$-methyltransferase \\
\hline AMK & $N$-acetyl-5-methoxyknuramine \\
\hline HIMOT & hydroxyindole-O-methyltransferase \\
\hline $\mathrm{Cd}$ & cadmium \\
\hline IDO & indoleamine 2,3-dioxygenase \\
\hline SOD & superoxide dismutase \\
\hline APX & ascorbate peroxidase \\
\hline CAT & catalase \\
\hline GPX & glutathione peroxidase \\
\hline ASA & antioxidants ascorbic acid \\
\hline GSH & glutathione \\
\hline DHAR & dehydroascorbate reductase \\
\hline MDHAR & monodehydroascorbate reductase \\
\hline $\mathrm{Cd}$ & cadmium \\
\hline $\mathrm{Fv} / \mathrm{Fm}$ & maximal quantum yield of PSII photochemistry \\
\hline PCs & phytochelatins \\
\hline $\mathrm{qP}$ & photochemical quenching \\
\hline NPQ & nonphotochemical quenching \\
\hline PAMPs & pathogen-associated molecular patterns \\
\hline MAMPs & microbe-associated molecular patterns \\
\hline
\end{tabular}

\section{References}

1. Hardeland, R. Melatonin in plants-Diversity of levels and multiplicity of functions. Front. Plant Sci. 2016, 7, 198. [CrossRef] [PubMed]

2. Sun, Q.; Zhang, N.; Wang, J.; Zhang, H.; Li, D.; Shi, J.; Li, R.; Weeda, S.; Zhao, B.; Ren, S.; et al. Melatonin promotes ripening and improves quality of tomato fruit during postharvest life. J. Exp. Bot. 2015, 66, 657-668. [CrossRef] [PubMed]

3. Hernández, I.G.; Gomez, F.J.V.; Cerutti, S.; Arana, M.V.; Silva, M.F. Melatonin in Arabidopsis thaliana acts as plant growth regulator at low concentrations and preserves seed viability at high concentrations. Plant Physiol. Biochem. 2015, 94, 191-196. [CrossRef] [PubMed]

4. Manchester, L.C.; Coto-Montes, A.; Boga, J.A.; Andersen, L.P.H.; Zhou, Z.; Galano, A.; Vriend, J.; Tan, D.X.; Reiter, R.J. Melatonin: An ancient molecule that makes oxygen metabolically tolerable. J. Pineal Res. 2015, 59, 403-419. [CrossRef] [PubMed]

5. Prasad, T.K.; Anderson, M.D.; Martin, B.A.; Stewart, C.R. Evidence for chilling-induced oxidative stress in maize seedlings and a regulatory role for hydrogen peroxide. Plant Cell 1994, 6, 65-74. [CrossRef] [PubMed]

6. Foyer, C.H.; Lopez-Delgado, H.; Dat, J.F.; Scott, I.M. Hydrogen peroxide- and glutathione-associated mechanisms of acclimatory stress tolerance and signalling. Physiol. Plant. 1997, 100, 241-254. [CrossRef]

7. Reiter, R.; Tan, D.; Rosales-Corral, S.; Galano, A.; Zhou, X.; Xu, B. Mitochondria: Central organelles for melatonin's antioxidant and anti-aging actions. Molecules 2018, 23, 509. [CrossRef] [PubMed] 
8. Janice, L.; Tebello, N.; Santy, D. The interaction of melatonin and its precursors with aluminium, cadmium, copper, iron, lead, and zinc: An adsorptive voltammetric study. J. Pineal Res. 1998, 24, 15-21. [CrossRef]

9. Zhang, N.; Sun, Q.; Zhang, H.; Cao, Y.; Weeda, S.; Ren, S.; Guo, Y.-D. Roles of melatonin in abiotic stress resistance in plants. J. Exp. Bot. 2015, 66, 647-656. [CrossRef] [PubMed]

10. Hernández-Ruiz, J.; Arnao, M. Relationship of melatonin and salicylic acid in biotic/abiotic plant stress responses. Agronomy 2018, 8, 33. [CrossRef]

11. Tan, D.-X.; Manchester, L.; Esteban-Zubero, E.; Zhou, Z.; Reiter, R. Melatonin as a potent and inducible endogenous antioxidant: Synthesis and metabolism. Molecules 2015, 20, 18886-18906. [CrossRef] [PubMed]

12. Kang, K.; Kong, K.; Park, S.; Natsagdorj, U.; Kim, Y.S.; Back, K. Molecular cloning of a plant N-acetylserotonin methyltransferase and its expression characteristics in rice. J. Pineal Res. 2011, 50, 304-309. [CrossRef] [PubMed]

13. Hardeland, R. Taxon- and site-specific melatonin catabolism. Molecules 2017, 22, 2015. [CrossRef] [PubMed]

14. Kołodziejczyk, I.; Bałabusta, M.; Szewczyk, R.; Posmyk, M.M. The levels of melatonin and its metabolites in conditioned corn (Zea mays L.) and cucumber (Cucumis sativus L.) seeds during storage. Acta Physiol. Plant. 2015, 37, 105. [CrossRef]

15. Erland, L.A.E.; Turi, C.E.; Saxena, P.K. Serotonin: An ancient molecule and an important regulator of plant processes. Biotechnol. Adv. 2016, 34, 1347-1361. [CrossRef] [PubMed]

16. Erland, L.; Saxena, P.K. Beyond a neurotransmitter: The role of serotonin in plants. Neurotransmitter 2017, 4, e1538. [CrossRef]

17. Bajwa, V.S.; Shukla, M.R.; Sherif, S.M.; Murch, S.J.; Saxena, P.K. Role of melatonin in alleviating cold stress in Arabidopsis thaliana. J. Pineal Res. 2014, 56, 238-245. [CrossRef] [PubMed]

18. Haitao, S.; Zhulong, C. The cysteine2/histidine2-type transcription factor ZINC FINGER OF ARABIDOPSIS THALIANA 6-activated C-REPEAT-BINDING FACTOR pathway is essential for melatonin-mediated freezing stress resistance in Arabidopsis. J. Pineal Res. 2014, 57, 185-191. [CrossRef]

19. Ding, F.; Liu, B.; Zhang, S. Exogenous melatonin ameliorates cold-induced damage in tomato plants. Sci. Hortic. 2017, 219, 264-271. [CrossRef]

20. Ding, F.; Wang, M.; Liu, B.; Zhang, S. Exogenous melatonin mitigates photoinhibition by accelerating non-photochemical quenching in tomato seedlings exposed to moderate light during chilling. Front. Plant Sci. 2017, 8. [CrossRef] [PubMed]

21. Han, Q.-H.; Huang, B.; Ding, C.-B.; Zhang, Z.-W.; Chen, Y.-E.; Hu, C.; Zhou, L.-J.; Huang, Y.; Liao, J.-Q.; Yuan, S.; et al. Effects of melatonin on anti-oxidative systems and photosystem 11 in cold-stressed rice seedlings. Front. Plant Sci. 2017, 8. [CrossRef] [PubMed]

22. Gao, H.; Lu, Z.; Yang, Y.; Wang, D.; Yang, T.; Cao, M.; Cao, W. Melatonin treatment reduces chilling injury in peach fruit through its regulation of membrane fatty acid contents and phenolic metabolism. Food Chem. 2018, 245, 659-666. [CrossRef] [PubMed]

23. Li, H.; Chang, J.; Zheng, J.; Dong, Y.; Liu, Q.; Yang, X.; Wei, C.; Zhang, Y.; Ma, J.; Zhang, X. Local melatonin application induces cold tolerance in distant organs of Citrullus lanatus L. via long distance transport. Sci. Rep. 2017, 7, 40858. [CrossRef] [PubMed]

24. Li, X.; Brestic, M.; Tan, D.X.; Zivcak, M.; Zhu, X.; Liu, S.; Song, F.; Reiter, R.J.; Liu, F. Melatonin alleviates low PS I-limited carbon assimilation under elevated $\mathrm{CO}_{2}$ and enhances the cold tolerance of offspring in chlorophyll $b$-deficient mutant wheat. J. Pineal Res. 2018, 64, e12453. [CrossRef] [PubMed]

25. Zhao, H.; Zhang, K.; Zhou, X.; Xi, L.; Wang, Y.; Xu, H.; Pan, T.; Zou, Z. Melatonin alleviates chilling stress in cucumber seedlings by up-regulation of CsZat12 and modulation of polyamine and abscisic acid metabolism. Sci. Rep. 2017, 7, 4998. [CrossRef] [PubMed]

26. Shi, H.; Tan, D.X.; Reiter, R.J.; Ye, T.; Yang, F.; Chan, Z. Melatonin induces class A1 heat-shock factors (HSFA1s) and their possible involvement of thermotolerance in Arabidopsis. J. Pineal Res. 2015, 58, 335-342. [CrossRef] [PubMed]

27. Xu, W.; Cai, S.Y.; Zhang, Y.; Wang, Y.; Ahammed, G.J.; Xia, X.J.; Shi, K.; Zhou, Y.H.; Yu, J.Q.; Reiter, R.J.; et al. Melatonin enhances thermotolerance by promoting cellular protein protection in tomato plants. J. Pineal Res. 2016, 61, 457-469. [CrossRef] [PubMed]

28. Qi, Z.-Y.; Wang, K.-X.; Yan, M.-Y.; Kanwar, K.M.; Li, D.-Y.; Wijaya, L.; Alyemeni, N.M.; Ahmad, P.; Zhou, J. Melatonin alleviates high temperature-induced pollen abortion in Solanum lycopersicum. Molecules 2018, 23, 386. [CrossRef] [PubMed] 
29. Zhang, J.; Shi, Y.; Zhang, X.; Du, H.; Xu, B.; Huang, B. Melatonin suppression of heat-induced leaf senescence involves changes in abscisic acid and cytokinin biosynthesis and signaling pathways in perennial ryegrass (Lolium perenne L.). Environ. Exp. Bot. 2017, 138, 36-45. [CrossRef]

30. Alam, M.N.; Zhang, L.; Yang, L.; Islam, M.R.; Liu, Y.; Luo, H.; Yang, P.; Wang, Q.; Chan, Z. Transcriptomic profiling of tall fescue in response to heat stress and improved thermotolerance by melatonin and 24-epibrassinolide. BMC Genom. 2018, 19, 224. [CrossRef] [PubMed]

31. Chen, Z.; Xie, Y.; Gu, Q.; Zhao, G.; Zhang, Y.; Cui, W.; Xu, S.; Wang, R.; Shen, W. The AtrbohF-dependent regulation of ROS signaling is required for melatonin-induced salinity tolerance in Arabidopsis. Free Radic. Biol. Med. 2017, 108, 465-477. [CrossRef] [PubMed]

32. Zheng, X.; Tan, D.X.; Allan, A.C.; Zuo, B.; Zhao, Y.; Reiter, R.J.; Wang, L.; Wang, Z.; Guo, Y.; Zhou, J.; et al. Chloroplastic biosynthesis of melatonin and its involvement in protection of plants from salt stress. Sci. Rep. 2017, 7, 41236. [CrossRef] [PubMed]

33. Wang, L.Y.; Liu, J.L.; Wang, W.X.; Sun, Y. Exogenous melatonin improves growth and photosynthetic capacity of cucumber under salinity-induced stress. Photosynthetica 2016, 54, 19-27. [CrossRef]

34. Li, H.; Chang, J.; Chen, H.; Wang, Z.; Gu, X.; Wei, C.; Zhang, Y.; Ma, J.; Yang, J.; Zhang, X. Exogenous melatonin confers salt stress tolerance to watermelon by improving photosynthesis and redox homeostasis. Front. Plant Sci. 2017, 8, 295. [CrossRef] [PubMed]

35. Arora, D.; Bhatla, S.C. Melatonin and nitric oxide regulate sunflower seedling growth under salt stress accompanying differential expression of $\mathrm{Cu} / \mathrm{Zn}$ SOD and Mn SOD. Free Radic. Biol. Med. 2017, 106, 315-328. [CrossRef] [PubMed]

36. Chen, Y.-E.; Mao, J.-J.; Sun, L.-Q.; Huang, B.; Ding, C.-B.; Gu, Y.; Liao, J.-Q.; Hu, C.; Zhang, Z.-W.; Yuan, S.; et al. Exogenous melatonin enhances salt stress tolerance in maize seedlings by improving antioxidant and photosynthetic capacity. Physiol. Plant. 2018. [CrossRef] [PubMed]

37. Zuo, B.; Zheng, X.; He, P.; Wang, L.; Lei, Q.; Feng, C.; Zhou, J.; Li, Q.; Han, Z.; Kong, J. Overexpression of MzASMT improves melatonin production and enhances drought tolerance in transgenic Arabidopsis thaliana plants. J. Pineal Res. 2014, 57, 408-417. [CrossRef] [PubMed]

38. Wang, L.; Feng , C.; Zheng, X.; Guo, Y.; Zhou, F.; Shan, D.; Liu, X.; Kong, J. Plant mitochondria synthesize melatonin and enhance the tolerance of plants to drought stress. J. Pineal Res. 2017, 63, e12429. [CrossRef]

39. Wang, Y.; Cai, S.; Yin, L.; Shi, K.; Xia, X.; Zhou, Y.; Yu, J.; Zhou, J. Tomato HsfA1a plays a critical role in plant drought tolerance by activating ATG genes and inducing autophagy. Autophagy 2015, 11, 2033-2047. [CrossRef] [PubMed]

40. Ye, J.; Wang, S.; Deng, X.; Yin, L.; Xiong, B.; Wang, X. Melatonin increased maize (Zea mays L.) seedling drought tolerance by alleviating drought-induced photosynthetic inhibition and oxidative damage. Acta Physiol. Plant. 2016, 38, 48. [CrossRef]

41. Fleta-Soriano, E.; Díaz, L.; Bonet, E.; Munné-Bosch, S. Melatonin may exert a protective role against drought stress in maize. J. Agron. Crop Sci. 2017, 203, 286-294. [CrossRef]

42. Cui, G.; Zhao, X.; Liu, S.; Sun, F.; Zhang, C.; Xi, Y. Beneficial effects of melatonin in overcoming drought stress in wheat seedlings. Plant Physiol. Biochem. 2017, 118, 138-149. [CrossRef] [PubMed]

43. Antoniou, C.; Chatzimichail, G.; Xenofontos, R.; Pavlou, J.J.; Panagiotou, E.; Christou, A.; Fotopoulos, V. Melatonin systemically ameliorates drought stress-induced damage in Medicago sativa plants by modulating nitro-oxidative homeostasis and proline metabolism. J. Pineal Res. 2017, 62, e12401. [CrossRef] [PubMed]

44. Byeon, Y.; Lee, H.Y.; Hwang, O.J.; Lee, H.J.; Lee, K.; Back, K. Coordinated regulation of melatonin synthesis and degradation genes in rice leaves in response to cadmium treatment. J. Pineal Res. 2015, 58, 470-478. [CrossRef] [PubMed]

45. Lee, K.; Choi, G.H.; Back, K. Cadmium-induced melatonin synthesis in rice requires light, hydrogen peroxide, and nitric oxide: Key regulatory roles for tryptophan decarboxylase and caffeic acid $O$-methyltransferase. J. Pineal Res. 2017, 63, e12441. [CrossRef] [PubMed]

46. Lee, K.; Back, K. Overexpression of rice serotonin $N$-acetyltransferase 1 in transgenic rice plants confers resistance to cadmium and senescence and increases grain yield. J. Pineal Res. 2017, 62, e12392. [CrossRef] [PubMed]

47. Cai, S.Y.; Zhang, Y.; Xu, Y.P.; Qi, Z.Y.; Li, M.Q.; Ahammed, G.J.; Xia, X.J.; Shi, K.; Zhou, Y.H.; Reiter, R.J.; et al. Hsfa1a upregulates melatonin biosynthesis to confer cadmium tolerance in tomato plants. J. Pineal Res. 2017, 62, e12387. [CrossRef] [PubMed] 
48. Hasan, M.K.; Ahammed, G.J.; Yin, L.; Shi, K.; Xia, X.; Zhou, Y.; Yu, J.; Zhou, J. Melatonin mitigates cadmium phytotoxicity through modulation of phytochelatins biosynthesis, vacuolar sequestration, and antioxidant potential in Solanum lycopersicum L. Front. Plant Sci. 2015, 6, 601. [CrossRef] [PubMed]

49. Gu, Q.; Chen, Z.; Yu, X.; Cui, W.; Pan, J.; Zhao, G.; Xu, S.; Wang, R.; Shen, W. Melatonin confers plant tolerance against cadmium stress via the decrease of cadmium accumulation and reestablishment of microRNA-mediated redox homeostasis. Plant Sci. 2017, 261, 28-37. [CrossRef] [PubMed]

50. Nawaz, M.A.; Jiao, Y.; Chen, C.; Shireen, F.; Zheng, Z.; Imtiaz, M.; Bie, Z.; Huang, Y. Melatonin pretreatment improves vanadium stress tolerance of watermelon seedlings by reducing vanadium concentration in the leaves and regulating melatonin biosynthesis and antioxidant-related gene expression. J. Plant Physiol. 2018, 220, 115-127. [CrossRef] [PubMed]

51. Zuo, Z.; Sun, L.; Wang, T.; Miao, P.; Zhu, X.; Liu, S.; Song, F.; Mao, H.; Li, X. Melatonin improves the photosynthetic carbon assimilation and antioxidant capacity in wheat exposed to Nano-ZnO stress. Molecules 2017, 22, 1727. [CrossRef] [PubMed]

52. Yool, L.H.; Yeong, B.; Kyoungwhan, B. Melatonin as a signal molecule triggering defense responses against pathogen attack in Arabidopsis and tobacco. J. Pineal Res. 2014, 57, 262-268. [CrossRef]

53. Shi, H.; Chen, Y.; Tan, D.X.; Reiter, R.J.; Chan, Z.; He, C. Melatonin induces nitric oxide and the potential mechanisms relate to innate immunity against bacterial pathogen infection in Arabidopsis. J. Pineal Res. 2015, 59, 102-108. [CrossRef]

54. Yool, L.H.; Kyoungwhan, B. Melatonin is required for $\mathrm{H}_{2} \mathrm{O}_{2}$ - and NO-mediated defense signaling through MAPKKK3 and OXI1 in Arabidopsis thaliana. J. Pineal Res. 2017, 62, e12379. [CrossRef]

55. Zhang, S.; Liu, S.; Zhang, J.; Reiter, R.J.; Wang, Y.; Qiu, D.; Luo, X.; Khalid, A.R.; Wang, H.; Feng, L.; et al. Synergistic anti-oomycete effect of melatonin with a biofungicide against oomycetic black shank disease. J. Pineal Res. 2018, e12492. [CrossRef] [PubMed]

56. Wei, Y.; Hu, W.; Wang, Q.; Zeng, H.; Li, X.; Yan, Y.; Reiter, R.J.; He, C.; Shi, H. Identification, transcriptional and functional analysis of heat-shock protein 90s in banana (Musa acuminata L.) highlight their novel role in melatonin-mediated plant response to Fusarium wilt. J. Pineal Res. 2017, 62, e12367. [CrossRef] [PubMed]

57. Zhang, S.; Zheng, X.; Reiter, R.J.; Feng, S.; Wang, Y.; Liu, S.; Jin, L.; Li, Z.; Datla, R.; Ren, M. Melatonin attenuates potato late blight by disrupting cell growth, stress tolerance, fungicide susceptibility and homeostasis of gene expression in Phytophthora infestans. Front. Plant Sci. 2017, 8. [CrossRef] [PubMed]

58. Wei, Y.; Chang, Y.; Zeng, H.; Liu, G.; He, C.; Shi, H. Rav transcription factors are essential for disease resistance against cassava bacterial blight via activation of melatonin biosynthesis genes. J. Pineal Res. 2018, 64, e12454. [CrossRef] [PubMed]

59. Zhang, H.; Liu, X.; Chen, T.; Ji, Y.; Shi, K.; Wang, L.; Zheng, X.; Kong, J. Melatonin in apples and juice: Inhibition of browning and microorganism growth in apple juice. Molecules 2018, 23, 521. [CrossRef] [PubMed]

60. Ueno, M.; Kihara, J.; Arase, S. Tryptamine and sakuranetin accumulation in sekiguchi lesions associated with the light-enhanced resistance of the lesion mimic mutant of rice to Magnaporthe oryzae. J. Gen. Plant Pathol. 2015, 81, 1-4. [CrossRef]

61. Mukherjee, S.; David, A.; Yadav, S.; Baluška, F.; Bhatla, S.C. Salt stress-induced seedling growth inhibition coincides with differential distribution of serotonin and melatonin in sunflower seedling roots and cotyledons. Physiol. Plant. 2014, 152, 714-728. [CrossRef] [PubMed]

62. Lozeron, H.; Maggiora, A.; Jadassohn, W. Protection of vicia faba equina against x-rays by serotonin. Experientia 1964, 20, 390-391. [CrossRef] [PubMed]

63. Lee, H.Y.; Back, K. Mitogen-activated protein kinase pathways are required for melatonin-mediated defense responses in plants. J. Pineal Res. 2016, 60, 327-335. [CrossRef] [PubMed]

64. Lee, H.Y.; Back, K. 2-hydroxymelatonin promotes the resistance of rice plant to multiple simultaneous abiotic stresses (combined cold and drought). J. Pineal Res. 2016, 61, 303-316. [CrossRef] [PubMed]

65. Back, K.; Tan, D.X.; Reiter, R.J. Melatonin biosynthesis in plants: Multiple pathways catalyze tryptophan to melatonin in the cytoplasm or chloroplasts. J. Pineal Res. 2016, 61, 426-437. [CrossRef] [PubMed]

66. Byeon, Y.; Lee, K.; Park, Y.I.; Park, S.; Back, K. Molecular cloning and functional analysis of serotonin $N$-acetyltransferase from the cyanobacterium Synechocystis sp. PCC 6803. J. Pineal Res. 2013, 55, 371-376. [CrossRef] [PubMed] 
67. Byeon, Y.; Lee, H.J.; Lee, H.Y.; Back, K. Cloning and functional characterization of the Arabidopsis $\mathrm{N}$-acetylserotonin $\mathrm{O}$-methyltransferase responsible for melatonin synthesis. J. Pineal Res. 2016, 60, 65-73. [CrossRef] [PubMed]

68. Noé, W.; Mollenschott, C.; Berlin, J. Tryptophan decarboxylase from catharanthus roseus cell suspension cultures: Purification, molecular and kinetic data of the homogenous protein. Plant Mol. Biol. 1984, 3, 281-288. [CrossRef] [PubMed]

69. Fujiwara, T.; Maisonneuve, S.; Isshiki, M.; Mizutani, M.; Chen, L.; Wong, H.L.; Kawasaki, T.; Shimamoto, K. Sekiguchi lesion gene encodes a cytochrome p450 monooxygenase that catalyzes conversion of tryptamine to serotonin in rice. J. Biol. Chem. 2010, 285, 11308-11313. [CrossRef] [PubMed]

70. Kang, S.; Kang, K.; Lee, K.; Back, K. Characterization of rice tryptophan decarboxylases and their direct involvement in serotonin biosynthesis in transgenic rice. Planta 2007, 227, 263-272. [CrossRef] [PubMed]

71. Park, S.; Kang, K.; Lee, K.; Choi, D.; Kim, Y.-S.; Back, K. Induction of serotonin biosynthesis is uncoupled from the coordinated induction of tryptophan biosynthesis in pepper fruits (Capsicum annuum) upon pathogen infection. Planta 2009, 230, 1197-1206. [CrossRef] [PubMed]

72. Park, S.; Byeon, Y.; Back, K. Functional analyses of three ASMT gene family members in rice plants. J. Pineal Res. 2013, 55, 409-415. [CrossRef] [PubMed]

73. Kang, K.; Lee, K.; Park, S.; Byeon, Y.; Back, K. Molecular cloning of rice serotonin N-acetyltransferase, the penultimate gene in plant melatonin biosynthesis. J. Pineal Res. 2013, 55, 7-13. [CrossRef] [PubMed]

74. Byeon, Y.; Lee, H.Y.; Lee, K.; Back, K. Caffeic acid O-methyltransferase is involved in the synthesis of melatonin by methylating $N$-acetylserotonin in Arabidopsis. J. Pineal Res. 2014, 57, 219-227. [CrossRef] [PubMed]

75. Tan, D.-X.; Manchester, L.C.; Mascio, P.D.; Martinez, G.R.; Prado, F.M.; Reiter, R.J. Novel rhythms of $N^{1}$-acetyl- $N^{2}$-formyl-5-methoxykynuramine and its precursor melatonin in water hyacinth: Importance for phytoremediation. FASEB J. 2007, 21, 1724-1729. [CrossRef] [PubMed]

76. Byeon, Y.; Back, K. Molecular cloning of melatonin 2-hydroxylase responsible for 2-hydroxymelatonin production in rice (Oryza sativa). J. Pineal Res. 2015, 58, 343-351. [CrossRef] [PubMed]

77. Lee, K.; Zawadzka, A.; Czarnocki, Z.; Reiter, R.J.; Back, K. Molecular cloning of melatonin 3-hydroxylase and its production of cyclic 3-hydroxymelatonin in rice (Oryza sativa). J. Pineal Res. 2016, 61, 470-478. [CrossRef] [PubMed]

78. Shi, H.; Chen, K.; Wei, Y.; He, C. Fundamental issues of melatonin-mediated stress signaling in plants. Front. Plant Sci. 2016, 7. [CrossRef] [PubMed]

79. Byeon, Y.; Back, K. Melatonin synthesis in rice seedlings in vivo is enhanced at high temperatures and under dark conditions due to increased serotonin $N$-acetyltransferase and $N$-acetylserotonin methyltransferase activities. J. Pineal Res. 2013, 56, 189-195. [CrossRef] [PubMed]

80. Park, S.; Lee, K.; Kim, Y.S.; Back, K. Tryptamine 5-hydroxylase-deficient sekiguchi rice induces synthesis of 5-hydroxytryptophan and $N$-acetyltryptamine but decreases melatonin biosynthesis during senescence process of detached leaves. J. Pineal Res. 2012, 52, 211-216. [CrossRef] [PubMed]

81. Kang, K.; Lee, K.; Park, S.; Kim, Y.S.; Back, K. Enhanced production of melatonin by ectopic overexpression of human serotonin $\mathrm{N}$-acetyltransferase plays a role in cold resistance in transgenic rice seedlings. J. Pineal Res. 2010, 49, 176-182. [CrossRef] [PubMed]

82. Park, S.; Kang, K.; Lee, S.W.; Ahn, M.-J.; Bae, J.-M.; Back, K. Production of serotonin by dual expression of tryptophan decarboxylase and tryptamine 5-hydroxylase in Escherichia coli. Appl. Microbiol. Biotechnol. 2011, 89, 1387-1394. [CrossRef] [PubMed]

83. Wang, L.; Zhao, Y.; Reiter, R.J.; He, C.; Liu, G.; Lei, Q.; Zuo, B.; Zheng, X.D.; Li, Q.; Kong, J. Changes in melatonin levels in transgenic 'Micro-Tom' tomato overexpressing ovine AANAT and ovine HIOMT genes. J. Pineal Res. 2014, 56, 134-142. [CrossRef] [PubMed]

84. Lee, H.Y.; Byeon, Y.; Tan, D.X.; Reiter, R.J.; Back, K. Arabidopsis serotonin N-acetyltransferase knockout mutant plants exhibit decreased melatonin and salicylic acid levels resulting in susceptibility to an avirulent pathogen. J. Pineal Res. 2015, 58, 291-299. [CrossRef] [PubMed]

85. Byeon, Y.; Back, K. Low melatonin production by suppression of either serotonin $N$-acetyltransferase or $\mathrm{N}$-acetylserotonin methyltransferase in rice causes seedling growth retardation with yield penalty, abiotic stress susceptibility, and enhanced coleoptile growth under anoxic conditions. J. Pineal Res. 2016, 60, 348-359. [CrossRef] [PubMed] 
86. Huang, Y.-H.; Liu, S.-J.; Yuan, S.; Guan, C.; Tian, D.-Y.; Cui, X.; Zhang, Y.-W.; Yang, F.-Y. Overexpression of ovine AANAT and HIOMT genes in switchgrass leads to improved growth performance and salt-tolerance. Sci. Rep. 2017, 7, 12212. [CrossRef] [PubMed]

87. Choudhury, F.K.; Rivero, R.M.; Blumwald, E.; Mittler, R. Reactive oxygen species, abiotic stress and stress combination. Plant J. 2017, 90, 856-867. [CrossRef] [PubMed]

88. Dietz, K.-J. Thiol-based peroxidases and ascorbate peroxidases: Why plants rely on multiple peroxidase systems in the photosynthesizing chloroplast? Mol. Cells 2016, 39, 20-25. [CrossRef] [PubMed]

89. Kerchev, P.I.; Waszczak, C.; Lewandowska, A.; Willems, P.; Shapiguzov, A.; Li, Z.; Alseekh, S.; Mühlenbock, P.; Hoebrichts, F.; Huang, J.J.; et al. Lack of GLYCOLATE OXIDASE1, but not GLYCOLATE OXIDASE2, attenuates the photorespiratory phenotype of CATALASE2-deficient Arabidopsis. Plant Physiol. 2016, 171, 1704-1719. [CrossRef] [PubMed]

90. Shi, H.; Wang, X.; Tan, D.X.; Reiter, R.J.; Chan, Z. Comparative physiological and proteomic analyses reveal the actions of melatonin in the reduction of oxidative stress in bermuda grass (Cynodon dactylon (L). Pers.). J. Pineal Res. 2015, 59, 120-131. [CrossRef] [PubMed]

91. Bose, J.; Rodrigo-Moreno, A.; Shabala, S. Ros homeostasis in halophytes in the context of salinity stress tolerance. J. Exp. Bot. 2014, 65, 1241-1257. [CrossRef] [PubMed]

92. Tan, D.X.; Hardeland, R.; Manchester, L.C.; Poeggeler, B.; Lopez-Burillo, S.; Mayo, J.C.; Sainz, R.M.; Reiter, R.J. Mechanistic and comparative studies of melatonin and classic antioxidants in terms of their interactions with the ABTS cation radical. J. Pineal Res. 2003, 34, 249-259. [CrossRef] [PubMed]

93. Lowes, D.A.; Webster, N.R.; Murphy, M.P.; Galley, H.F. Antioxidants that protect mitochondria reduce interleukin- 6 and oxidative stress, improve mitochondrial function, and reduce biochemical markers of organ dysfunction in a rat model of acute sepsis. Br. J. Anaesth. 2013, 110, 472-480. [CrossRef] [PubMed]

94. Gitto, E.; Tan, D.X.; Reiter, R.J.; Karbownik, M.; Manchester, L.C.; Cuzzocrea, S.; Fulia, F.; Barberi, I. Individual and synergistic antioxidative actions of melatonin: Studies with vitamin E, vitamin c, glutathione and desferrrioxamine (desferoxamine) in rat liver homogenates. J. Pharm. Pharmacol. 2001, 53, 1393-1401. [CrossRef] [PubMed]

95. Romero, A.; Ramos, E.; de Los Ríos, C.; Egea, J.; Del Pino, J.; Reiter, R.J. A review of metal-catalyzed molecular damage: Protection by melatonin. J. Pineal Res. 2014, 56, 343-370. [CrossRef] [PubMed]

96. Rodriguez, C.; Mayo, J.C.; Sainz, R.M.; Antolín, I.; Herrera, F.; Martín, V.; Reiter, R.J. Regulation of antioxidant enzymes: A significant role for melatonin. J. Pineal Res. 2004, 36, 1-9. [CrossRef] [PubMed]

97. Wang, P.; Yin, L.; Liang, D.; Li, C.; Ma, F.; Yue, Z. Delayed senescence of apple leaves by exogenous melatonin treatment: Toward regulating the ascorbate-glutathione cycle. J. Pineal Res. 2012, 53, 11-20. [CrossRef] [PubMed]

98. Baker, N.R. Chlorophyll fluorescence: A probe of photosynthesis in vivo. Annu. Rev. Plant Biol. 2008, 59, 89-113. [CrossRef] [PubMed]

99. Ma, X.; Zhang, J.; Burgess, P.; Rossi, S.; Huang, B. Interactive effects of melatonin and cytokinin on alleviating drought-induced leaf senescence in creeping bentgrass (Agrostis stolonifera). Environ. Exp. Bot. 2018, 145, 1-11. [CrossRef]

100. Shi, H.; Qian, Y.; Tan, D.X.; Reiter, R.J.; He, C. Melatonin induces the transcripts of CBF/DREB1s and their involvement in both abiotic and biotic stresses in Arabidopsis. J. Pineal Res. 2015, 59, 334-342. [CrossRef] [PubMed]

101. Murch, S.J.; KrishnaRaj, S.; Saxena, P.K. Tryptophan is a precursor for melatonin and serotonin biosynthesis in in vitro regenerated St. John's wort (Hypericum perforatum L. cv. Anthos) plants. Plant Cell Rep. 2000, 19, 698-704. [CrossRef]

102. Radwanski, E.R.; Last, R.L. Tryptophan biosynthesis and metabolism: Biochemical and molecular genetics. Plant Cell 1995, 7, 921-934. [CrossRef] [PubMed]

103. Ueno, M.; Shibata, H.; Kihara, J.; Honda, Y.; Arase, S. Increased tryptophan decarboxylase and monoamine oxidase activities induce sekiguchi lesion formation in rice infected with magnaporthe grisea. Plant J. 2003, 36, 215-228. [CrossRef] [PubMed]

104. Pickles, V.R.; Sutcliffe, J.F. The effects of 5-hydroxytryptamine, indole-3-acetic acid, and some other substances, on pigment effusion, sodium uptake, and potassium efflux, by slices of red beetroot in vitro. Biochim. Biophys. Acta 1955, 17, 244-251. [CrossRef] 
105. Álvarez-Diduk, R.; Galano, A.; Tan, D.X.; Reiter, R.J. N-acetylserotonin and 6-hydroxymelatonin against oxidative stress: Implications for the overall protection exerted by melatonin. J. Phys. Chem. 2015, 119, 8535-8543. [CrossRef] [PubMed]

106. Tsuda, K.; Katagiri, F. Comparing signaling mechanisms engaged in pattern-triggered and effector-triggered immunity. Curr. Opin. Plant Biol. 2010, 13, 459-465. [CrossRef] [PubMed]

107. Cui, H.; Tsuda, K.; Parker, J.E. Effector-triggered immunity: From pathogen perception to robust defense. Annu. Rev. Plant Biol. 2015, 66, 487-511. [CrossRef] [PubMed]

108. Shi, H.-T.; Li, R.-J.; Cai, W.; Liu, W.; Wang, C.-L.; Lu, Y.-T. Increasing nitric oxide content in Arabidopsis thaliana by expressing rat neuronal nitric oxide synthase resulted in enhanced stress tolerance. Plant Cell Physiol. 2012, 53, 344-357. [CrossRef] [PubMed]

109. Liu, Y.; Zhang, S. Phosphorylation of 1-aminocyclopropane-1-carboxylic acid synthase by MPK6, a stress-responsive mitogen-activated protein kinase, induces ethylene biosynthesis in Arabidopsis. Plant Cell 2004, 16, 3386-3399. [CrossRef] [PubMed]

110. Mandal Mihir, K.; Suren, H.; Ward, B.; Boroujerdi, A.; Kousik, C. Differential roles of melatonin in plant-host resistance and pathogen suppression in cucurbits. J. Pineal Res. 2018, e12505. [CrossRef] [PubMed]

111. Weeda, S.; Zhang, N.; Zhao, X.; Ndip, G.; Guo, Y.; Buck, G.A.; Fu, C.; Ren, S. Arabidopsis transcriptome analysis reveals key roles of melatonin in plant defense systems. PLoS ONE 2014, 9, e93462. [CrossRef] [PubMed]

(C) 2018 by the authors. Licensee MDPI, Basel, Switzerland. This article is an open access article distributed under the terms and conditions of the Creative Commons Attribution (CC BY) license (http:/ / creativecommons.org/licenses/by/4.0/). 